\title{
Variation in the amount and activity of esterase 6 in a natural population of Drosophila melanogaster
}

\author{
Anne Y. Game*† and \\ John G. Oakeshott*†
}

\author{
* Department of Population Biology, Research School \\ of Biological Sciences, Australian National University, \\ PO Box 475, Canberra City ACT 2601, Australia. \\ $\uparrow$ CSIRO, Division of Entomology, PO Box 1700, \\ Canberra City ACT 2601, Australia.
}

Forty-two homozygous lines each isoallelic for the Esterase 6 (Est-6) locus were extracted from a natural population of Drosophila melanogaster. Homogenates of 4-5 day old virgin adults of each sex from several replicate cultures of each line were assayed for EST6 activity. Depending on the line, males had from three to nine times more EST6 activity than females. Both sexes showed highly significant differences in EST6 activity among lines, with $3 \cdot 2$ and $2 \cdot 7$ fold differences between highest and lowest lines for males and females respectively. However, the variation in EST6 activity among lines was only weakly correlated across the two sexes. Female EST6 activity did not differ significantly across the six electrophoretic variants of EST6 found among the 42 lines. On the other hand, a significant proportion of the variation among lines in male EST6 activity could be explained by differences among the six electromorphs. However, most of these differences were due to the relatively high activities of males from two relatively rare electromorphs and there were no significant differences in male activity among the four more common EST6 electromorphs. Radial immunodiffusion assays with polyclonal anti-EST6 antibody established that differences among lines in male EST6 activity were largely due to differences in the number of EST6 protein molecules, with negligible differences in their specific activities. It is concluded that the natural population segregates for genetic variance with large effects on the amount of EST6 protein; that there is little overlap in the variance expressed in the two sexes; and that most of the variance is different from the polymorphisms for electrophoretically detectable variants of EST6.

\section{INTRODUCTION}

Evidence of non-random spatial and temporal variation in electromorph frequencies suggests that a significant proportion of enzyme polymorphisms are not neutral to natural selection (Barker and East, 1980; Piazza et al., 1981). It is presumed that the selection operates on variation in biochemical functions correlated with the electrophoretic differences and indeed high levels of variation have been found in enzyme activities, both in vitro and in vivo (Cavener and Clegg, 1981; Laurie-Ahlberg et al., 1982).

The question then arises as to the nature of the correlation between the electrophoretic and activity variation (McDonald, 1983; Eanes, 1987). Are the two forms of variation directly connected because the structural differences detected by electrophoresis also affect the specific activity of the enzyme? Or is the correlation indirect, due to gametic disequilibrium between the electromorphs and cis-acting regulatory polymorphisms affecting the amount of enzyme produced? The plausibility of the latter explanation is enhanced by accumulating evidence for large gametic disequilibria among nucleotide polymorphisms in the coding and $5^{\prime}$ regulatory sequences of the alcohol dehydrogenase gene of Drosophila melanogaster (Kreitman and Aguade, 1986; Aquadro et al., 1986). However the two alternative explanations have seldom been distinguished because information is required on both the amount and specific activities of the polymorphic electromorphs.

The present paper provides such information for the Esterase 6 polymorphism of $D$. melanogaster. The Esterase 6 enzyme (EST6, EC 3.1.1.1) is encoded by the Est-6 locus, located at 69AI on chromosome III (Wright, 1963; Akam et al, 1978). High resolution electrophoresis detects ten polymorphic variants of EST6 (Cooke et al., 1987) and the recurrence of large-scale latitudinal clines indicates that at least some of the variants differ under natural selection (Anderson and Oakeshott, 1984). The mechanism of selection is likely to involve reproductive fitness, since most EST6 is produced in the sperm ejaculatory duct 
of the adult male, from where it is transferred to the female during mating (Richmond et al., 1980; Richmond and Senior, 1981).

The present analysis utilises 42 homozygous third chromosome isoallelic lines extracted from a single natural population and including six EST6 electrophoretic variants. An endpoint spectrophotometric assay is used to determine the in vitro EST6 activities of 4-5 day old virgin adult males and females. Radial immunodiffusion techniques using polyclonal anti-EST6 antibody are then used to assess the contributions of variation in the amounts and specific activities of EST6 protein to the EST6 activity differences found among males of the 42 lines.

\section{MATERIALS AND METHODS}

The 42 isoallelic lines were isolated from a population at Coffs Harbour, on the east coast of New South Wales (Australia), by crossing and backcrossing wild-caught males to the third chromosome balancer line TM3 (Cooke et al., 1987). The lines used were homozygous for wild-caught third chromosomes and had been maintained in the laboratory for about 15 generations before this experiment. None of these 42 lines carried the $\ln (3 L) P$ inversion.

Standard electrophoretic procedures (Oakeshott et al., 1981) had resolved four major mobility variants of EST6 among the 42 lines; EST6-VF, EST6-F', EST6-F, and EST6-S. However, subsequent application of precision cellulose acetate electrophoresis revealed six variants, the major EST6-F and EST6-S variants each being resolved into two variants distinguished only by minor mobility differences (Cooke et al., 1987). In the nomenclature of Cooke et al. (1987), the six variants, with their correspondence to the major classes and their relative anodal mobilities at $p \mathrm{H} 8.5$ in parentheses, were; EST6-1 (=EST6-VF, 1·18), EST6-2 (=EST6-F' $1 \cdot 12)$, EST6-4 (= EST6F, 1.07), EST6-5 (=EST6-F, 1.06), EST6-8 $(=$ EST6-S, 1.00) and EST6-9 (=EST6-S, 0.99).

EST6 activity was assayed in homogenates of virgin adult males and females aged 4-5 days since emergence. Homogenates were prepared from between four and ten separate cultures for each sex from each line. For each homogenate between 4 and 50 flies (usually about 25) were weighed and homogenised in $10 \mu \mathrm{l} /$ female or $20 \mu \mathrm{l} /$ male of grinding buffer $(0.1 \mathrm{M}$ phosphate $p \mathrm{H} 6.8$, $10 \mu \mathrm{g} / \mathrm{ml}$ BSA). Homogenates were then cen- trifuged for $25 \mathrm{~min}$ at $15,000 \mathrm{~g}$ and the supernatant stored at $-20^{\circ} \mathrm{C}$ until used.

EST6 activity was determined by a modification of the end-point spectrophotometric assay of Sheehan et al. (1979). Homogenate equivalent to $0.45 \mathrm{mg}$ of males or $1.3 \mathrm{mg}$ of females (about $10 \mu \mathrm{l}$ ) was incubated for 30 minutes at $27^{\circ} \mathrm{C}$ in a final volume of $1 \mathrm{ml}$ grinding buffer containing $10^{-2} \mathrm{M}$ $\beta$-napthyl acetate (Sigma), $10^{-5} \mathrm{M}$ eserine (Sigma) and $5 \times 10^{-4} \mathrm{M} p$-chloromercuribenzoate (Sigma). One $\mathrm{ml}$ of a $2: 5$ one per cent Diazoblue (Sigma): five per cent SDS dye solution was then added and the mixture left at $22^{\circ} \mathrm{C}$ for five minutes before its $\mathrm{OD}_{550}$ was determined. After subtracting the $\mathrm{OD}_{550}$ for control samples without homogenate, the EST6 activity of the homogenate was expressed as $\mathrm{OD}_{550} / \mathrm{mg}$ fly $\times 10^{3}$. (Essentially the same pattern of results was obtained if activity values were standardised by the number rather than the weight of homogenised flies). The eserine and $p$-chloromercuribenzoate were added to inhibit the activity of other esterases and the specificity of the assay for EST6 activity was confirmed by the lack of detectable activity in homogenates of the EST6 null stock of Sheehan et al. (1979).

It was necessary to carry out the activity assays on several different days. In order to avoid confounding variation among lines with variation among assay days, the homogenates assayed on each day were randomised with respect to lines.

Radial immunodiffusion (RID) assays of EST6 protein amounts were performed following a method similar to that of Dickinson et al. (1984). The RID assays were carried out on three of the homogenates of males from each line assayed for EST6 activity. (RID assays were not carried out on homogenates of females because their lower EST6 activity levels made accurate assays more difficult.) $20 \mathrm{ml}$ gels of 2.5 per cent agarose in grinding buffer were prepared, each containing $75 \mu \mathrm{l}$ of polyclonal rabbit anti-EST6 antibody (gift of R. C. Richmond). Each gel contained 36 evenly spaced circular wells and two replicates of three dilutions $(1 \cdot 5,3,6 \mu l)$ of five homogenates to be tested plus one standard mass homogenate were added to these wells. The plates were then incubated for $14-15$ hours at $4^{\circ} \mathrm{C}$, before being stained with 0.01 per cent $\beta$-napthyl propionate (Sigma), 0.4 per cent fast garnet GBC salt (Sigma) in $0 \cdot 1 \mathrm{M}$ phosphate buffer $p \mathrm{H} 6 \cdot 8$.

Following Mancini et al. (1965) and Dickinson et al. (1984), the areas of the stained circles were used to determine the amount of EST6 crossreacting material (CRM). The log of the area was plotted against dilution for each extract under test 
and the linear part of the plot compared to that for the control extract to give a relative estimate of CRM. The specific activity of EST6 molecules was calculated as the ratio of activity/CRM for each homogenate assayed for both measures.

All measures of EST6 activity, CRM and specific activity were subjected to hierarchical analyses of variance nested by electromorphs, lines within electromorphs and homogenates within lines. Separate analyses were carried out for the two sexes. Following the procedures of Sokal and Rohlf (1969), significance tests were carried out on mean squares corrected to account for unequal sample sizes across cells. The $F$ values shown below were based on untransformed data but tests based on logarithmic transformations yielded similar results.

\section{RESULTS}

Fig. 1 shows the mean EST6 activities of 4-5 day old virgin adults of each sex from each of the 42 isoallelic lines. Consistent with previous observations (Sheehan et al., 1979; Stein et al., 1984), EST6 activity differed substantially between the two sexes, with values from three to nine times higher in males than females. However, within each sex, there were also substantial differences in EST6 activity among lines $\left(F_{36,366}=10.98, P<0.001\right.$ for males; $F_{36,313}=9 \cdot 14, P<0 \cdot 001$ for females), with a 3.2 fold range of values in males $(1075 \pm 69$ to $3444 \pm 310)$ and a $2 \cdot 7$ fold range in females $(210 \pm$ 10 to $563 \pm 13)$. Moreover the variation among lines was significantly but not strongly correlated across the two sexes $\left(r=0 \cdot 32, r^{2}=0 \cdot 11, P<0 \cdot 05\right)$. This correlation was not simply a consequence of a correlation between the two sexes within individual cultures because the latter correlation was negligible (data not shown).

Table 1 shows the mean EST6 activities for males and for females and the means of their ratios

Table 1 Means and standard errors of three measures of EST6 activity for each of six EST6 electromorphs. The three measures are the in vitro EST6 activities of 4-5 day old virgin males and females and the ratio of the activities in the two sexes. The units of activity are $O D_{550}$ per $\mathrm{mg}$ fly $\times 10^{3}$. The six electromorphs were identified by precision electrophoretic procedures and their correspondence to the four major classes resolved by standard electrophoretic methods is also shown (see Materials and Methods for details). The number of lines $(N)$ assayed for each electromorph is also given

\begin{tabular}{llllll}
\hline \multicolumn{2}{l}{$\begin{array}{l}\text { Electromorph } \\
\text { Standard Precision }\end{array}$} & & $\begin{array}{l}\text { Male } \\
\text { activity }\end{array}$ & $\begin{array}{l}\text { Female } \\
\text { activity }\end{array}$ & $\begin{array}{l}\text { Male activity: } \\
\text { female } \\
\text { activity }\end{array}$ \\
\hline VF & 1 & 2 & $3019 \pm 162$ & $347 \pm 31$ & $8 \cdot 24 \pm 0 \cdot 65$ \\
$\mathrm{~F}^{\prime}$ & 2 & 1 & $2398 \pm 100$ & $325 \pm 18$ & $7 \cdot 81 \pm 0 \cdot 70$ \\
$\mathrm{~F}$ & 4 & 6 & $2169 \pm 68$ & $420 \pm 10$ & $5 \cdot 34 \pm 0 \cdot 21$ \\
$\mathrm{~F}$ & 5 & 3 & $1847 \pm 66$ & $343 \pm 20$ & $5 \cdot 82 \pm 0 \cdot 48$ \\
$\mathrm{~S}$ & 8 & 22 & $1961 \pm 35$ & $364 \pm 7$ & $5 \cdot 78 \pm 0 \cdot 14$ \\
$\mathrm{~S}$ & 9 & 8 & $1719 \pm 51$ & $375 \pm 11$ & $4 \cdot 97 \pm 0 \cdot 22$ \\
\hline
\end{tabular}

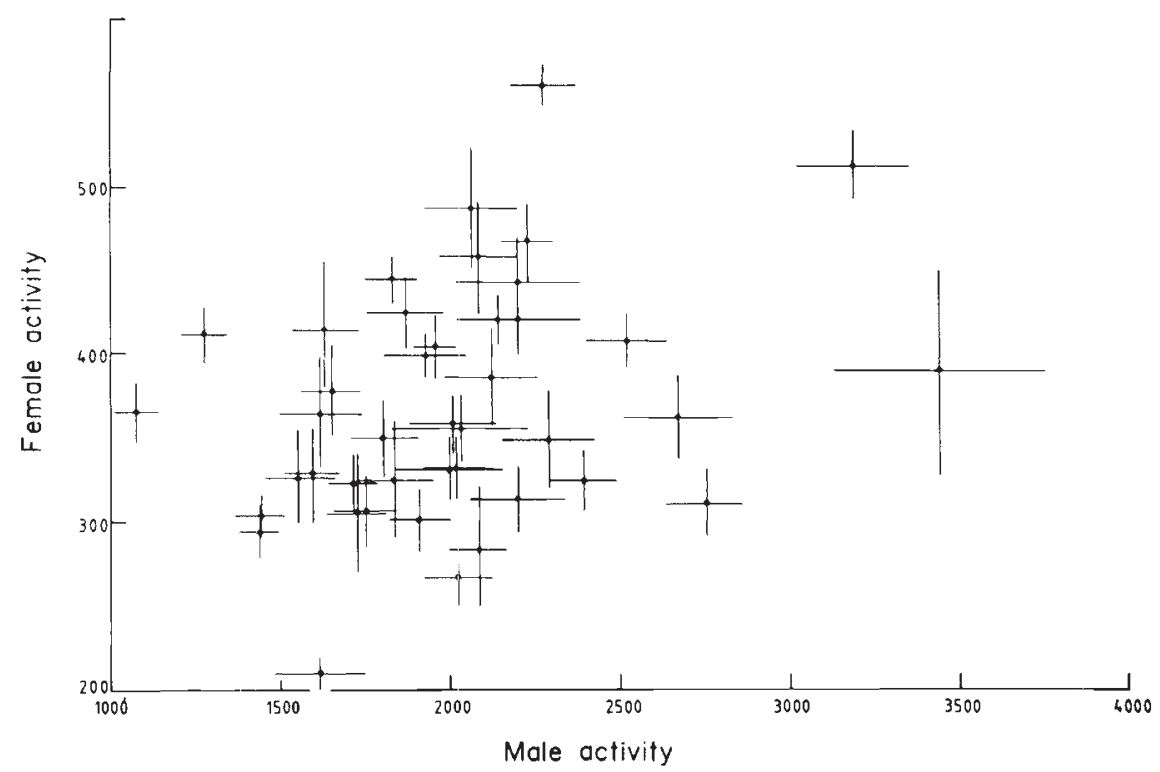

Figure 1 Means and standard errors of the in vitro EST6 activities of 4-5 day old virgin males and females from the 42 lines. Units are $\mathrm{OD}_{550}$ per $\mathrm{mg}$ fly $\times 10^{3}$. 
in each of the six EST6 electromorphs which Cooke et al. (1987) found among the 42 lines. Differences among the six electromorphs were statistically significant for EST6 activity in males $\left(F_{5,36}=3.28, \quad P<0.05\right)$, and for the ratio of activities in the two sexes $\left(F_{5,36}=2 \cdot 49, P<0.05\right)$, but not for the activity in females $\left(F_{5,36}=0 \cdot 84\right.$, $P>0.05)$. As Table 1 shows, the significant differences among the six electromorphs for male activity and the ratio in the two sexes were largely due to relatively high values for the rarest and most anodal electromorphs, the EST6-1 and EST6-2 variants of Cooke et al. (1987) (previously denoted EST6-VF and EST6-F'). The EST6-1 variant showed the most extreme values and if the EST6-1 data were omitted from the analyses then the differences among genotypes were no longer statistically significant $\left(F_{4,35}=1.70, P>0.05\right.$ for male activity; $F_{4,34}=1.57, P>0.05$ for the ratio). There were thus no significant differences for any of the three activity measures, either between the major mobility classes EST6-F and EST6-S, or between the minor mobility variants within these classes, EST6-4 and EST6-5 (within EST6-F), and EST6-8 and EST6-9 (within EST6-S).

Fig. 2 shows the mean amounts of EST6 protein (CRM) in 4-5 day old virgin adult males from each of the 42 isoallelic lines. There was a strong and highly significant correlation across the lines between EST6 activities and EST6 amounts ( $r=$ $\left.0 \cdot 80, r^{2}=0 \cdot 64, P<0 \cdot 001\right)$. As with EST6 activity there were large differences between lines in EST6 amount $\left(F_{36,85}=2.22, P<0.01\right)$, with a 3.7 fold range in values between the highest and lowest lines.

As Table 2 shows, the male EST6 CRM values showed a pattern of variation among the six electromorphs which was similar to that for the corresponding male EST6 activity data (Table 1). In the case of the CRM values the variation among electromorphs did not reach statistical significance $\left(F_{5,36}=1.74, \quad P>0.05\right)$, but once again the EST6-1 variant yielded the highest values, with EST6-2 next and negligible variation among the four variants in the major EST6-F and EST6-S classes.

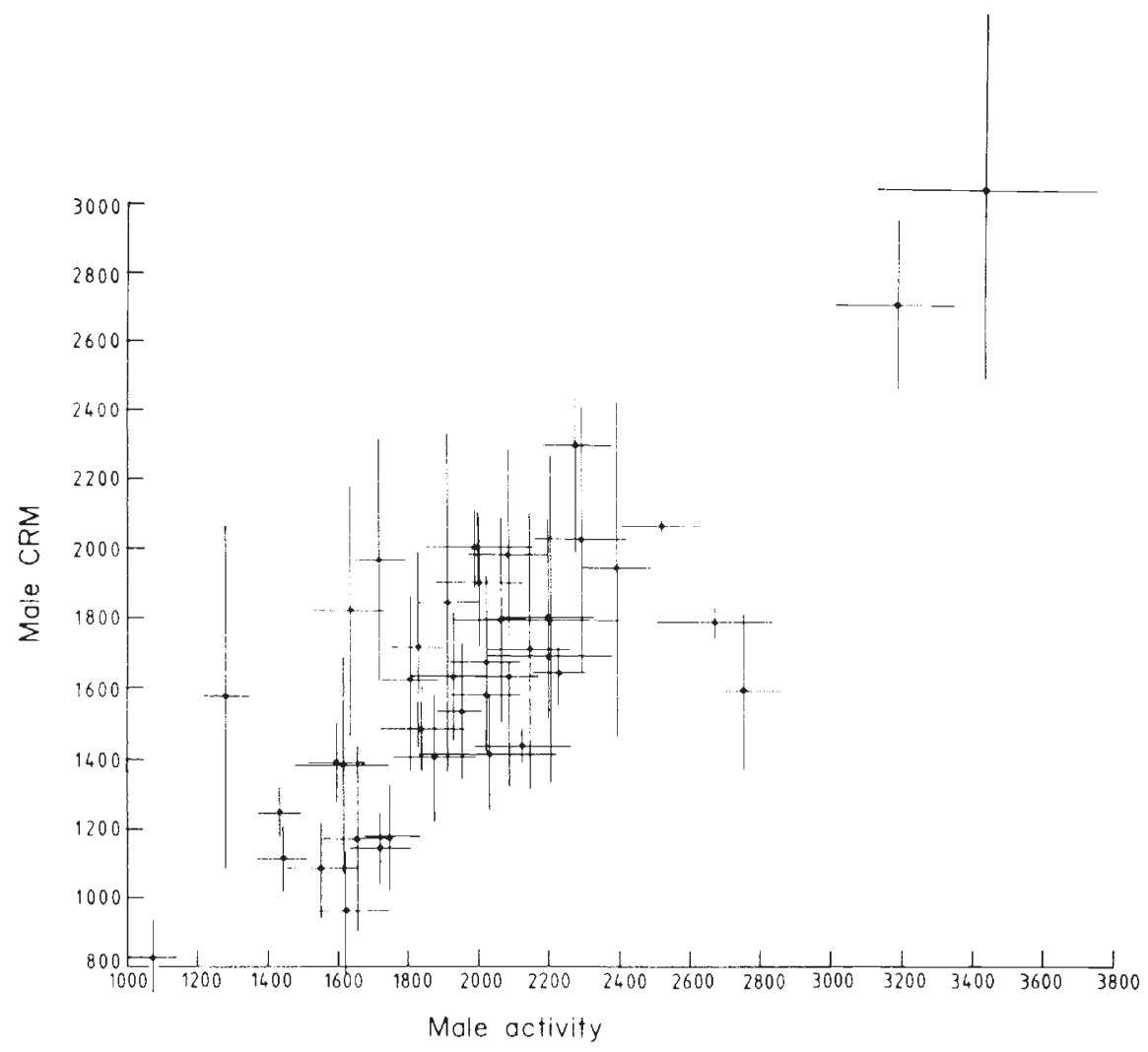

Figure 2 Means and standard errors of the amount (CRM) and in vitro activity of EST6 protein in 4-5 day old virgin males from the 42 lines. Units for activity are as in fig. 1 and units for CRM are arbitrary (see Materials and Methods). 
For those homogenates of males assayed for both measures, the ratio of EST6 activity to EST6 amount gave an estimate of the specific activity of EST6 protein. This estimate did not vary significantly among either the 42 isoallelic lines (Fig.

Table 2 Means and standard errors of EST6 CRM and specific activity in 4-5 day old virgin males for each of six EST6 electromorphs identified by precision electrophoresis. The units for CRM are arbitrary and specific activity is defined as the ratio of EST6 activity to CRM. As in table 1, the correspondence of these electromorphs with those identified by standard electrophoretic procedures are given, as are the number of lines $(N)$ assayed for each electromorph

\begin{tabular}{llrll}
\hline \multicolumn{2}{l}{ Electromorph } & & & \\
\cline { 1 - 1 } Standard & Precision & $N$ & CRM & $\begin{array}{l}\text { Specific } \\
\text { activity }\end{array}$ \\
\hline VF & 1 & 2 & $2475 \pm 475$ & $1298 \pm 199$ \\
$\mathrm{~F}^{\prime}$ & 2 & 1 & $1950 \pm 484$ & $1402 \pm 255$ \\
$\mathrm{~F}$ & 4 & 6 & $1666 \pm 91$ & $1296 \pm 60$ \\
$\mathrm{~F}$ & 5 & 3 & $1738 \pm 191$ & $1138 \pm 58$ \\
$\mathrm{~S}$ & 8 & 22 & $1640 \pm 62$ & $1276 \pm 31$ \\
$\mathrm{~S}$ & 9 & 8 & $1495 \pm 118$ & $1237 \pm 81$ \\
\hline
\end{tabular}

3, $\left.F_{36,82}=1 \cdot 30, P>0 \cdot 05\right)$ or the six electromorphs (Table 2, $F_{5,36}=0.50, P>0.05$ ). The correlation between EST6 activities and specific activities across the 42 lines was also negligible $(r=0 \cdot 04$, $\left.r^{2}=0 \cdot 005, P>0 \cdot 05\right)$.

\section{DISCUSSION}

This study has revealed substantial inherited variation for EST6 activity among 42 third chromosome isoallelic lines extracted from a natural population of $D$. melanogaster. A $3 \cdot 2$ fold difference was found between the lines with highest and lowest activity in 4-5 day old virgin males, and a 2.7 fold difference was found between the lines most extreme for activity in virgin 4-5 day old females. Moreover the variation in the two sexes was only weakly correlated across lines.

The majority of EST6 activity in males occurs in the anterior sperm ejaculatory duct, with all the activity in females (and the remainder in males) spread throughout the remainder of the body

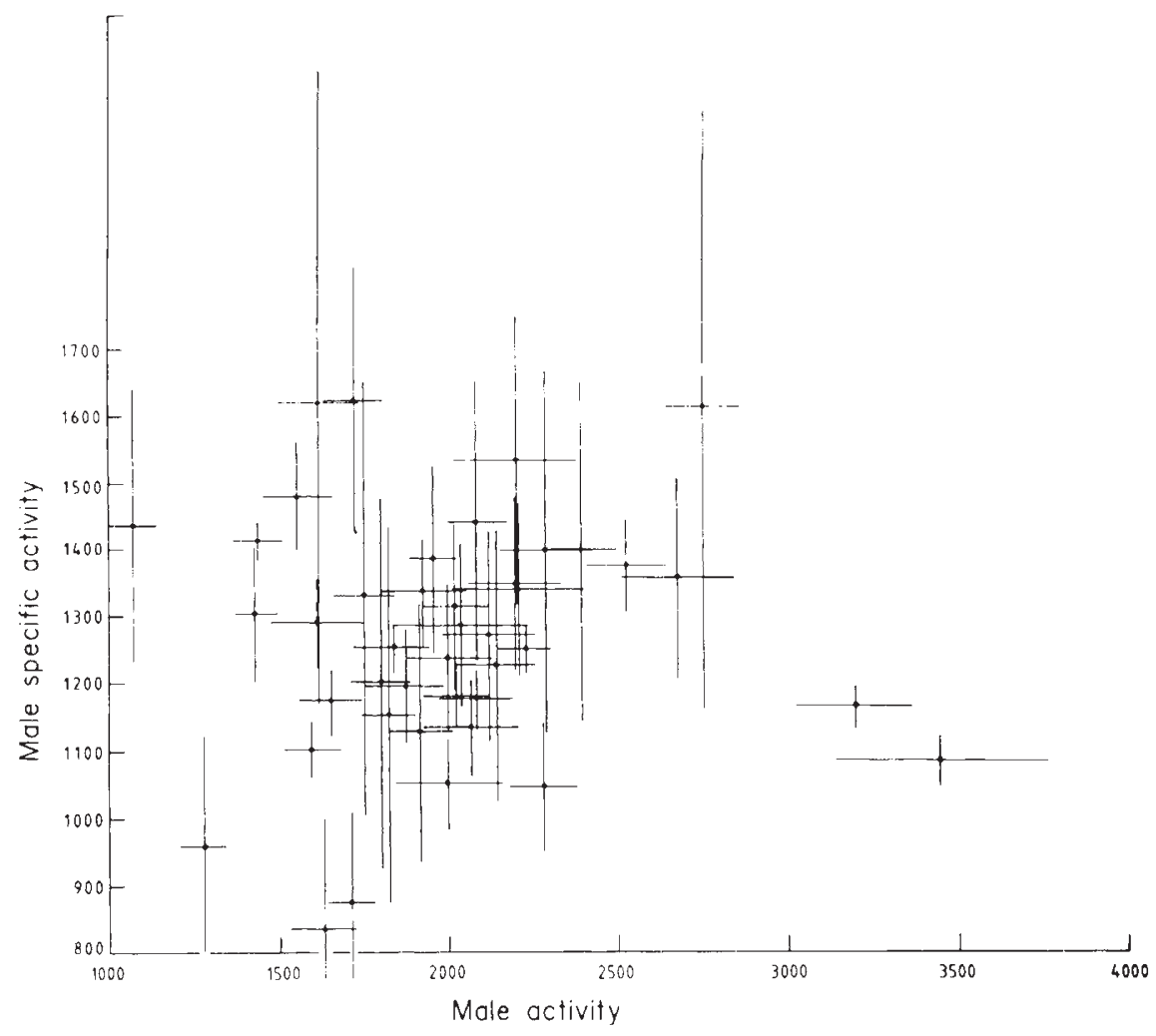

Figure 3 Means and standard errors of the specific activity of EST6 protein in 4-5 day old virgin males from the 42 lines. Specific activity is calculated as the ratio of EST6 activity to CRM (see fig. 2). 
(Sheehan et al., 1979; Stein et al., 1984; A. Y. Game, unpublished data); therefore the data for males largely reflect variation in the EST6 activity of the ejaculatory duct, while the data for females reflect variation in the EST6 activity of the remainder of the body.

Most of the variation detected in either sex is likely to be inherited on the third chromosome, on which the structural locus for the EST6 enzyme is located (Wright, 1963). This is because the backcrossing programme to the TM3 balancer used to make each line isoallelic for a different wildderived third chromosome would also require each line to derive all its $X$ chromosomes and about 75 per cent of its second and fourth chromosomes from the balancer stock (Cooke et al., 1987). The elimination of $\mathrm{X}$-linked variation is particularly noteworthy since a pilot survey among chromosome substitution lines by Tepper et al. (1982, 1984) found that the only significant effects on the EST6 activity of males (females not being assayed) were due to the $\mathrm{X}$ and third chromosomes. The elimination of $\mathrm{X}$-effects in the present study also suggests that the variation we detected was not mediated by differences in juvenile hormone or ecdysone titres. Both hormones induce EST6 activity in isolated male abdomens ( Richmond and Tepper, 1983) and the $\mathrm{X}$ is the only chromosome to which factors affecting the titres of these hormones have been mapped (Kiss et al., 1978; Klose et al., 1980).

Although much of the activity variation was thus likely to be inherited on the (third) chromosome containing the EST6 locus, very little of the variation was associated with the structural variants of this locus detected by electrophoresis. No significant differences in female EST6 activity were found among the six EST6 electromorphs which Cooke et al. (1987) found among the 42 lines. Significant variation was found among the electromorphs for male EST6 activity but this was due to the high activity of the two rare, most anodal, EST6-1 and EST6-2 variants. Importantly, no consistent differences in male activity were found among the four more common electromorphs in the two major mobility classes EST6-F and EST6-S.

Radial immunodiffusion assays established that the differences among lines in male EST6 activity were largely due to differences in the number of EST6 protein molecules, with negligible differences in their specific activities. This was true both within and between electromorphs and could be explained by differences in the stability of EST6 protein or mRNA, in the translation of EST6 mRNA, or in the transcription of the EST6 gene.
We have no direct evidence as yet to discount the explanations based on differences in translational efficiency or in the stability of EST6 protein or mRNA. However it is relevant that the activity variation was largely uncorrelated across the two sexes; for these explanations to apply would require that the stability or translational differences were conditional upon sex/tissue. While precedents have been described in other systems for variation in translational efficiency or protein or mRNA stability, these differences have been "systemic", rather than conditional upon sex/tissue (e.g., Fagerhol and Cox, 1981; King and McDonald, 1987; Laurie-Ahlberg and Stam, 1987). On the other hand, several precedents for differences in levels of transcription have been described which are conditional upon tissue (e.g., Bishop and Wright, 1987; Maniatis et al., 1987). Such differences might arise through either cis-acting variation in tissue specific promoter elements or trans-acting variation in tissue specific transcription factors binding to these elements (Maniatis et al., 1987; Dynan, 1987, for reviews).

Finally it remains to consider the present results in relation to previous studies on the adaptive significance of EST6 polymorphism. The physiological function of EST6 in the female is unknown but the location of most male EST6 in the ejaculatory duct suggests a role in reproductive biology. Comparisons of the reproductive performance of males wild-type versus null for EST6 activity indeed confirm that at least some EST6 activity is important for male fitness (Gilbert, 1981; Gilbert et al., 1981). Consistent with this, EST6 null variants are found to occur most infrequently in natural populations (Voelker et al., 1980; Cambissa et al., 1982; Cooke et al., 1987).

Most studies of EST6 in natural populations however have concentrated not on the null activity variants, but on the polymorphism for the two common electrophoretic classes EST6-F and EST6-S. Oakeshott et al. (1981) and Anderson and Oakeshott (1984) found that EST6-S increases, and EST6-F decreases in frequency away from the equator in all three continents they studied. This suggested that the two variants are not selectively equivalent and that the relative fitness of genotypes producing EST6-S increases away from the equator. White et al. (1988) subsequently proposed that the physiological basis for the latitudinal clines involves temperature-dependent differences in the catalytic efficiencies of the two electromorphs. They found that purified EST6-S has greater activity than EST6-F over a range of substrate concentrations at assay temperatures around $15^{\circ} \mathrm{C}$, but that there is little difference in activity 
between the two variants at assay temperatures above $25^{\circ} \mathrm{C}$. They noted that the nature of these temperature dependent differences is consistent with the direction of the latitudinal clines and therefore suggested that these may be the differences on which the selection producing the clines is acting.

Our results are consistent with this proposition to the extent that they reveal no difference in activity between EST6-F and EST6-S at an assay temperature $\left(27^{\circ} \mathrm{C}\right)$ where the difference White et al. (1988) reported was very small anyway. More importantly however, the present results have also demonstrated that electrophoretically detectable structural variants of EST6 represent only a minor source of the activity variation on which selection might act. Most of the activity variation results from differences in the amount of EST6 protein and these differences are largely uncorrelated across the two sexes. A high priority for future work on the population genetics of EST6 therefore lies in elucidating the molecular basis and adaptive significance of this sex-specific variation in EST6 protein amount.

Acknowledgments We are indebted to Professor Rollin Richmond for the gift of the antibody and valuable help with the assay procedure. We would also like to thank S. W. McKechnie for assistance with the RID procedure and R. C. Richmond, P. H. Cooke, J. Karotam, E. A. van Papenrecht, M. A. Myers, R. J. Russell, M. A. Saad, A. Bortoli, M. J. Healy, K. Ardlie, W. R. Knibb and C. C. Collet for discussions and comments on this manuscript.

\section{REFERENCES}

AKAM, M. E., ROBERTS, D. B., RICHARDS, G. P. AND ASH. BURNER, M. 1978. Drosophila: the genetics of two major larval proteins. Cell, 13, 215-225.

ANDERSON, P. R. AND OAKESHOTT, J. G. 1984. Parallel geographical patterns of allozyme variation in two sibling Drosophila species. Nature, 308, 729-731.

AQUADRO, C. F., DESSE, S. F., BLAND, M. M., LANGLEY, C. H. AND LAURIE-AHLBERG, C. C. 1986. Molecular population genetics of the alcohol dehydrogenase gene region of Drosophila melanogaster. Genetics, 114, 1165-1190.

BARKER, J. S. F. AND EAST, P. D. 1980. Evidence for selection following perturbation of allozyme frequencies in a natural population of Drosophila. Nature, 284, 166-168.

BISHOP, C. P. AND WRIGHT, T. R. F. 1987. Ddc ${ }^{D E l}$, a mutant differentially affecting both stage and tissue specific expression of a Dopa decarboxylase in Drosophila. Genetics, 115, 477-491.

CAMBISSA. V.. NIGRO, L., DANIELI, G. A. AND COSTA, R. 1982. Occurrence of a rare allele at the Est6 locus in natural populations of Drosophila melanogaster. Boll. Zool., 49, 229-233.

CAVENER, D. R. AND CLEGG, M. T. 1981. Evidence for biochemical and physiological differences between enzyme genotypes in Drosophila melanogaster. Proc. Natl Acad. Sci. USA, 78, 4444-4447.
COOKE, P. H., RICHMOND, R. C. AND OAKESHOTT, J. G. 1987. High resolution electrophoretic variation at the esterase-6 locus in a natural population of Drosophila melanogaster. Heredity, 59, 259-264.

DICKINSON, W. J., ROWAN, R. G. AND BRENNAN, M. D. 1984. Regulatory gene evolution: Adaptive differences in expression of alcohol dehydrogenase in Drosophila melanogaster and D. simulans. Heredity, 52, 215-225.

DYNAN, W. S. 1987. What mechanisms underlie tissue-specific gene transcription. Trends in Genetics, 3, 121-122.

EANES, W. F. 1987. Allozymes and fitness: Evolution of a problem. TREE, 2, 44-48.

FAGERHOL, M. K. AND COX, D.W. 1981. The Pi polymorphism: genetic, biochemical and clinical aspects of human $\alpha_{1}$. antitrypsin. Adv. Human Genet., 11, 1-62.

GILBERT, D. G. 1981. Studies of esterase 6 in Drosophila melanogaster. VIII. Ejaculate esterase 6 and initial sperm use by females. J. Insect Physiol., 27, 641-650.

GILBERT, D. G., RICHMOND, R. C. AND SHEEHAN, K. B. 1981. Studies of esterase 6 in Drosophila melanogaster. VII. Remating times of females inserninated by males having active or null alleles. Behav. Genet., 11, 195-208.

KING, J. J. AND McDONALD, J. F. 1987. Post-translational control of alcohol dehydrogenase levels in Drosophila melanogaster. Genetics, 115, 693-699.

KISS, I., SZABAD, J. AND MAJOR, J. 1978. Genetic and developmental analysis of puparium formation in Drosophila. Molec: Gen. Genet., 164, 77-83.

KLOSE, W., GATEFF, E., EMMERICH, H. AND BEIKIRCH, H. 1980. Developmental studies on two ecdysone deficient mutants of Drosophila melanogaster. Wilh. Roux Arch. Dev. Biol., 189, 57-68.

KREITMAN, M. AND AGUADE, M. 1986. Excess polymorphism at the Adh locus in Drosophila melanogaster. Genetics, 114, 93-110.

LAURIE-AHLBERG, C. C. AND STAM, L. F. 1987. Use of Pelement-mediated transformation to identify the molecular basis of naturally occurring variants affecting $A d h$ expression in Drosophila melanogaster. Genetics, 115, 129140.

LAURIE-AHLBERG, C.C., WILTON, A. N., CURTSINGER, J. W. AND EMIGH, T. H. 1982. Naturally occuring enzyme activity variation in Drosophila melanogaster. I. Sources of variation for 23 enzymes. Genetics, 102, 191-206.

MANCINI, G., CARBONARA, A. O. AND HEREMANS, J. F. 1965. Immunochemical quantitation of antigens by single radial immunodiffusion. Immunochemistry, 2, 235-254.

MANIATIS, T., GOODBOURN, S. AND FISCHER, J. A. 1987. Regulation of inducible and tissue-specific gene expression. Science, 236, 1237-1245.

McDONALD, J. F. 1983. The molecular basis of adaptation: A critical review of relevant ideas and observations. Ann. Rev. Ecol. Syst., 14, 77-102.

OAKESHOTT, J. G., CHAMBERS, G. K., GIBSON, J. B. AND WILLCOCKS, D. A. 1981. Latitudinal relationships of esterase 6 and phosphoglucomutase gene frequencies in Drosophila melanogaster. Heredity, 47, 385-396.

PIAZZA, A., MENOZZI, P. AND CAVALLI-SFORZA, L. L. 1981. Synthetic gene frequency maps of man and selective effects of climate. Proc. Natl. Acad. Sci. USA, 78, 2638-2642.

RICHMOND, R. C., GILBERT, D. G., SHEEHAN, K. B., GROMKO, M. H. AND BUTTERWORTH, F. M. 1980. Esterase 6 and reproduction in Drosophila melanogaster. Science, 207, 1483-1485.

RICHMOND, R. C. AND SENIOR, A. 1981. Esterase 6 of Drosophila melanogaster: kinetics of transfer to females, decay in females and male recovery. $J$. Insect Physiol., 27, $849-853$ 
RICHMOND, R. C. AND TEPPER, C. S. 1983. Genetic and hormonal regulation of esterase 6 activity in male Drosophila melanogaster. In Ratazzi, M. C., Scandalios, J. G. and Whitt, G. S. (eds) Isozymes: Current Topics in Biological and Medical Research, vol. 9, A. R. Liss, New York, pp. $91-106$.

SHEEHAN, K., RICHMOND, R. C. AND COCHRANE, B. J. 1979. Studies of esterase- 6 in Drosophila melanogaster. III. The developmental pattern and tissue distribution. Insect Biochem., 9, 443-450.

SOKAL, R. R. AND ROHLF, F. J. 1969. Biometry, W. H. Freeman, San Francisco, 776 pp.

STEIN, S. P., TEPPER, C. S., ABLE, N. D. AND RICHMOND, R. C. 1984. Studies of esterase 6 in Drosophila melanogaster. XVI. Synthesis occurs in the male reproductive tract (anterior ejaculatory duct) and is modulated by juvenile hormone. Insect Biochem., 14, 527-537.
TEPPER, C. S., RICHMOND, R. C., TERRY, A. L. AND SENIOR, A. 1982. Studies of esterase 6 in Drosophila melanogaster. XI. Modification of esterase 6 activity by unlinked genes. Genet. Res., 40, 109-125.

TEPPER, C. S., TERRY, A. L., HOLMES, J. E. AND RICHMOND, R. C. 1984. Studies of esterase 6 in Drosophila melanogaster. XIV. Variation of esterase 6 levels controlled by unlinked genes in natural populations. Genet. Res., 43, 181-190.

VOELKER, R. A., LANGLEY, C. H., LEIGH BROWN, A. J., OHNISHI, S., DICKSON, B., MONTGOMERY, E. ANDSMITH, S. C. 1980. Enzyme null alleles in natural populations of Drosophila melanogaster: frequencies in a North Carolina population. Proc. Natl. Acad. Sci. USA, 77, 1091-1095.

WHITF, M. M., MANE, S. I). AND RICHMOND, R, C. 1988. Studies of esterase 6 in Drosophila melanogaster. XVIII. Biochemical differences between the slow and fast allozymes. Molec. Biol. Evol. 5, 41-62.

WRIGHT, T. R. F. 1963. The genetics of an esterase in Drosophila melanogaster. Genetics, 48, 787-801. 